\title{
AMERICAN RED CROSS CENTENNIAL
}

This year, the American Red Cross is celebrating its Centennial. It was founded by a fifty-nine year old woman named Clara Barton, who was born in North Oxford, Massachusetts, taught school for fifteen years, and was one of the first women to work for the United States government. During the American Civil War (1860-1865), she became known as the "Angel of the Battlefield" for her volunteer work among the wounded. After the Civil War, she went to Europe and learned firsthand about the Red Cross movement, participating in its relief effort during the Franco-Prussian War of 1870-1871. On her return home she worked with friends to found a Red Cross society. She first met with strong opposition from the government and it was only on 21 May 1881 that the American Association of the Red Cross was formed, with Miss Barton as president. In March 1882, President Chester A. Arthur signed, and the United States Senate ratified, the Geneva Convention of 1864, which led to the official recognition of the new society by the ICRC on 20 September 1882 . The Constitution of the society contained a special feature. It did not limit the activities of the Association to relief in case of war but it included compliance with a wish expressed at the International Red Cross Conference in Berlin (1869), relief assistance in case of natural disasters. ${ }^{1}$

The first challenge came in September 1881 after devastating forest fires in Michigan, but Miss Barton met it by collecting clothing and funds to send to the victims. In 1882 and 1884 , similar demands on the fledgling organization were met during massive flooding by the Ohio and Mississippi Rivers with Miss Barton directing relief operations from chartered steamboats. Her efforts reached a peak in 1889 following disas-

1 There is a very interesting résumé of the foundation of the American Red Cross and of the difficulties which preceded it in Bulletin international des Sociétés de secours aux militaires blessés, published by the ICRC, 1876, p 90, 1882, pp. 41, 92, 185 . 
trous flooding of Johnstown, Pennsylvania, when a dam break took a fearful toll of lives.

Clara Barton returned to the battlefield in 1898 during the SpanishAmerican War when she directed operations to provide food, nursing care and medical supplies to civilians and military forces in Cuba.

Two years later, in 1900, the Congress of the United States chartered the American Red Cross with responsibility for providing services to members of armed forces and relief to disaster victims. Following Miss Barton's retirement in 1904, internal administration and organization were improved under Mabel Boardman, a particularly talented leader. Under her direction, the congressional charter was revised in 1905 but contained the same obligations as the 1900 version. More than 75 years later, the American Red Cross continues to operate under this mandate.

In April 1906, the San Francisco earthquake provided another great challenge. President Theodore Roosevelt appointed the American Red Cross the nation's official relief agency to deal with the needs of the stricken city. The organization carried out the enormous task of mobilizing relief speedily and administering recovery efforts efficiently.

From 1909 through 1914, the American Red Cross continued to respond to the needs of the growing nation, developing programs in elementary hygiene and home care of the sick under pioneer nurse Jane Delano. Her Red Cross nurse enrollment became the official reserve for the Army and Navy in World War I. During the same years, the American Red Cross initiated first aid training in a variety of industries. The training handbook was translated into major foreign languages to meet the needs of immigrants then coming to America. Water safety training, meeting the needs of millions of Americans, took place during the same period, as swimming and lifesaving training were made available on an organized basis.

When Europe became a battlefield in 1914, the American Red Cross faced the emergency with only 107 chapters. The demands upon it, and the desire of Americans to assist in the relief effort, caused an explosive growth to 3,864 chapters by 1918 , incorporating nearly one fifth of the American population in membership.

In 1916, one year before America's entry into World War I, the American Red Cross organized 50 hospital units that later were assigned to France. Some 20,000 nurses were recruited for wartime service. Four ambulance sections served in northern Italy. Today still, Red Crossrecruited nurses serve in major American disaster relief operations, meeting the needs of sick and injured victims. In 1917, with the United States deeply involved in World War I, the junior Red Cross was formed, 
providing a channel for youth involvement in the relief effort. Today, Youth Services continue to provide a means for children to serve their communities and engage in international programs. Relief commissions were sent to France, Belgium, Russia and the Balkans to combat diseases and to aid civilians during and after the war.

After the war was over, the American Red Cross suggested to the French, British, Italian and Japanese Red Cross Societies that the vast resources which they had accumulated for intervention during the hostilities should be allotted to public health and to organizing relief in the event of natural disasters. In this way, the American Red Cross took a leading role in the foundation (5 May 1919) of the League of Red Cross Societies.

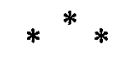

During the next twenty years, the American Red Cross improved its disaster techniques to cope with twentieth century demands and it started services to veterans returning from the First World War. Flooding of unprecedented severity occurred during 1927 and 1937 by the Ohio and Mississippi Rivers. Red Cross met the emergency through deployment of its increased volunteer strength. Disastrous drought and depression years during the thirties brought home the need for public health and nutrition. In hard-hit rural areas, the Red Cross was called upon by the government to assist in the distribution of food and clothing to families stunned by a national economic collapse of the highest magnitude.

During the same period, Red Cross took the first steps in blood donor recruitment which had become necessary to meet the demands of progressing medical technology. This modest beginning led to the formation of the present Red Cross Blood Services, today a major supplier of blood and blood products to the nation.

As the United States edged toward its involvement in a Second World War, the American Red Cross girded itself to support the demands to be placed on it. During the World War II period, the American Red Cross recruited more than 70,000 nurses for military duty, provided volunteers and staff in military hospitals, assigned staff to major military units in theaters of war around the globe, and supplied more than $13,000,000$ 
units of blood plasma for American servicemen. The organization also operated clubs and mobile club units for servicemen in overseas rest and recreation areas. From 1941 to 1946, the American people contributed $784,000,000$ dollars as well as millions of volunteer hours to meet the needs of servicemen and their families at home and abroad. During and following the conflict, the American Red Cross, along with other Red Cross Societies, the League of Red Cross Societies and the International Committee of the Red Cross, carried on extensive relief for civilian victims. American Red Cross assistance to Western Europe during the war years through 30 June 1946, amounted to about 152,000,000 dollars, of which about $67,000,000$ dollars represented the value of supplies purchased with government funds.

On the restoration of peace, the American Red Cross helped Red Cross Societies in stricken nations reorganize and cooperated with them in tracing and reuniting family members separated by the war. Nearly 40 years later, this effort continues, marking the awesome magnitude of the problem.

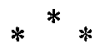

In the three and a half decades following World War II, advancing technology, the rising tide of social expectancy of the citizens, and improvements in transportation and communications have altered modes of delivery of service to Americans. External events at home and abroad have played their part in shaping a spirit of flexibility within the society.

During the same period, the United States was buffeted by natural disasters requiring enormous and costly relief efforts. These included a succession of severe floods and devastating hurricanes. The Red Cross is involved in almost 40,000 disaster relief operations annually, ranging from killer hurricanes to one-family fires and including special incidents such as the Three Mile Island nuclear accident and the Mount St. Helens eruptions. The increased cost of living and inflation in recent years have led the Red Cross to make strenuous efforts to obtain all resources needed by the victims to resume normal living. In addition, the Red Cross continues to provide emergency disaster relief in the way of food, clothing, shelter, blood and blood products, medical and nursing care, occupational tools, and other assistance to meet urgent needs.

Many Red Cross courses in health and safety, and in other services, have been devised to help people avoid emergencies, to prepare for those 
that cannot be avoided, and to cope with them when they do occur. Nursing and Health Services teach participants how to care for the ill and the elderly at home.

During the Korean conflict and the war in Indochina, Red Cross staff provided counseling, communications, and recreation support for members of the Armed Forces.

In the mid-1970's, when more than 150,000 refugees fled Indochina, and later, when another 130,000 persons left Cuba and Haiti, the Red Cross worked with other private agencies and the governement in centers where the refugees were temporarily housed pending their sponsorship in communities throughout the country. The Red Cross Refugee Locator Unit in Washington, D. C., continues to operate, reuniting families and friends from Indochina.

The decade of the seventies was a time of considerable growth for the Red Cross Blood Services, which now collect, process, and distribute more than half of the nation's total volunteer blood supply. A computerized inventory system enables blood centers to balance their overages and shortages with each other every day, thus preventing wastage.

The Red Cross has used the new technologies of the late twentieth century in various ways to enable it to give better service to people. A communications satellite has been available to link disaster-ravaged areas with the outside world. Video-tape has provided more effective means of training and furnishing public information.

Nearly $1,500,000$ persons give service to their community through the Red Cross, and nearly 4,200,000 individuals donate blood in Red Cross regional blood centers or are recruited for cooperating local blood banks. There are more than $4,000,000$ students in more than 21,000 elementary and secondary schools involved in Red Cross activities. Many of these young people are being trained for leadership roles in the future.

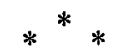

American Red Cross President George M. Elsey, in his book The American Red Cross: The First Century, examines the Society's first hundred years and gives some of his views concerning the organization and its service in the coming century.

He wrote inter alia: "The question arises: What will the 1980's and later decades mean to the (American) Red Cross? I would rather phrase the question: What will (American) Red Cross mean to the nation in the ' 80 s and beyond? 
"America need not fear the future, nor should its Red Cross. In its first century, the American Red Cross has evolved into a great national tradition of voluntary service. Millions of men, women and youth have educated people to help themselves and to help each other. Voluntary service will continue, but as the nation confronts future challenges, it will take new forms. Red Cross service rests on the bedrock philosophy that Americans can make the country a better place to live in by working together through voluntarism... We have the conviction that the lessons of its first hundred years will provide a secure foundation for the Red Cross to meet the challenges of the future through new services, new relationships and new talents."

The International Review thanks the American Red Cross for contributing this article and at the same time extends its congratulations and warm wishes. 